\title{
The Back-Door Governance of Crime: Confiscating Criminal Assets in the UK
}

\section{Yulia Chistyakova $^{1}$ (D) David S. Wall ${ }^{2} \cdot$ Stefano Bonino $^{3}$}

Published online: 7 September 2019

(C) The Author(s) 2019

\begin{abstract}
The policy and practice of confiscating criminal assets to control crime and recover illicit wealth has come to occupy a central position in national and international policing and security agendas. However, this practice has raised many questions about agencies' abilities to measure success and also the social impacts of asset confiscation. This article contributes to the crime control debates by exploring contemporary literature and drawing upon a subset of data from the Joint Asset Recovery Database (JARD). The first part of the article briefly outlines the key legislative provisions of asset recovery in the UK. The second part explores what the JARD data tells us about the performance of the confiscation of proceeds of crime approach and it will argue that seizing illicit wealth has not been the main priority for government. It will argue instead that the proceeds of crime approach, originally designed to target the most serious and organised crime, has effectively become a disciplining and symbolic tool against relatively lower level acquisitive crimes. It concludes that while technical measures of impact remain inconclusive, it is more important to subject the ideological underpinnings of the proceeds of crime law to critical scrutiny.
\end{abstract}

Keywords Proceeds of Crime - Organised Crime - Confiscation Order - Asset Recovery · JARD Joint Asset Recovery Database

\section{Introduction}

The idea of countering organised crime and terrorism by depriving offenders of the proceeds of their criminal activities has come to occupy a central position in national and international

Yulia Chistyakova

Y.Chistyakova@ljmu.ac.uk

1 School of Humanities and Social Science, Liverpool John Moores University, John Foster Building 80-98 Mount Pleasant, Liverpool L3 5UZ, UK

2 Centre for Criminal Justice Studies, School of Law, University of Leeds, Leeds, UK

3 Faculty of Law, University of Trento, Trento, Italy 
policing and security agendas. The 1988 UN Convention Against Illicit Traffic in Narcotic Drugs and Psychotropic Substances (the Vienna Convention) made the laundering of drug proceeds an international offence (Stessen 2000). The Vienna Convention has established a Financial Action Task Force (FATF) to oversee implementation. Today, there are a number of international regimes dealing with asset recovery. FATF, for example, focuses on global antimoney laundering (AML) and countering terrorist financing (CTF) and considers confiscation of the proceeds of crime to be fundamental to the effectiveness of its AML/CTF measures (FATF 2018). UN Conventions, in particular, the 2003 UN Convention against corruption, focus more narrowly on recovering money stolen by corrupt governments and politicians and returning the money to the country of origin. This is also the priority for the Organisation for Economic Cooperation and Development (OECD 2018). The EU, on the other hand, has developed a broader approach, attempting to seize and recover proceeds from any acquisitive crime (Ligeti and Simonato 2017). Since 1990, the Council of Europe and the EU have adopted a number of legal instruments aimed to strengthen cooperation between countries, harmonise national legislation and enhance mutual recognition (Ligeti and Simonato 2017; The European Council 2018). In the UK, asset recovery pursues multiple objectives. The Performance and Innovation Unit (PIU) Report published in 2000 sets out the key aims of the pursuit and recovery of the proceeds of crime in the fight against organised crime. The key message of the report is that 'most organised crime is motivated by profit' (PIU 2000: 5) and that the removal of criminal assets generally shows potential offenders that crime will not pay. Removing criminal assets also disrupts criminal networks and markets and, in so doing, deters people from crime and removes negative role models from communities, not to mention improving crime detection rates and assisting the fight against money laundering (PIU 2000: 16). In addition, the recovery of crime proceeds is also expected to be cost-effective and even capable of generating 'significant revenue flows' for the public good (PIU 2000: 6; see also Fleming 2008; Abadinsky 2003; Albanese 1996).

Critics have, however, questioned the appropriateness, scope and use of such powers and the effectiveness of the laws. Naylor (2001: 148) noted that after 15 years of use of the forfeiture approach in the United States there was no robust evidence of its effectiveness. Similarly, Woodiwiss has argued that various crime control measures including asset forfeitures 'have made US organised crime problems more complex but they have not come close to solving them' (Woodiwiss 2003: 24). Naylor, Levi and Reuter, and Sproat question the very definition of the scope and nature of the problem being addressed. Not only is the amount of criminal money in circulation and therefore available for confiscation unknown, we also wonder whether the problem for society that 'proceeds of crime' constitutes has been adequately conceptualised (Naylor 2001: 147; Levi and Reuter 2006; Sproat 2012). Other critics have questioned the basic assumption that the asset recovery automatically leads to crime reduction and disruption (Innes and Sheptycki 2004; King and Walker 2014; Bullock and Lister 2014). Similarly, the lack of evidence of impact upon the anti-money laundering regime on the ability to offend has been observed (Levi and Reuter 2006). Furthermore, implementation of the seizure of proceeds of crime policy has been subject to criticism. In particular, it is argued that targeting offenders and offences by confiscation proceedings is often driven by its social visibility, rather than crime control considerations alone (Bullock 2010; Sproat 2012). Critics also point out the danger of the unanticipated damage that can be caused by the policies (Naylor 2001). It has been argued, for example, that the confiscation of drug proceeds may have knock on effects and lead to an increase in violence at drug markets. This is because they adapt to punitive law enforcement strategies by becoming more flexible 
and violent, with larger, more static players replacing smaller, more flexible ones (Dorn and South 1990). Moreover, a loss of jobs can also result from confiscated companies going bankrupt or being liquidated - a typical situation in Italy for example (see Riccardi 2014; Savona and Riccardi 2015). The 'criminal lifestyle' assumptions and the low burden of proof in civil recovery cases are considered to be particularly problematic by some commentators due to the punitiveness of these measures, their impact on the rights of defendants and the hardship that this may cause to them and their families (Lea 2004; Bullock and Lister 2014). Another, though less central issue, is the degree to which the policy actually generates revenue due to the high cost associated with asset recovery procedures (see NAO 2013), and high levels of monetary attrition (Bullock and Lister 2014, Bullock 2014; Levi and Osofsky 1995; The Public Accounts Committee 2014; Home Office 2014, NAO 2013). To illustrate this, the estimated cost of the end-to-end confiscation process, according to the National Audit Office (NAO 2013) was $£ 102 \mathrm{~m}$, while the money collected by enforcement agencies in 2012-13 was $£ 133 \mathrm{~m}$. With regard to attrition, Bullock et al. in a study of the enforcement status of orders imposed in 2006 found that the amount paid was just $38 \%$ of the aggregate value of orders (Bullock et al. 2009).

The dearth of published data on recovered assets is an issue that impedes rigorous research in this area. Other than the work of Bullock and colleagues (Bullock 2010, 2014; Bullock and Lister 2014; Bullock et al. 2009), little is known about asset recovery and its impact (Levi 1997, 2013; Harvey and Lau 2008; Naylor 1999; Levi and Reuter 2006; Levi and Maguire 2004; Mackenzie and Hamilton-Smith 2011). The ongoing political backing of the proceeds of crime regime is surprising given the lack of robust empirical evidence of its outcomes observed earlier (see also van Duyne 2003, Harvey and Lau 2008).

This article seeks to address and discuss the dearth of published data on recovered assets and to contribute to the ongoing debate over the current confiscation of proceeds of crime policy and practice by exploring the contemporary literature and by drawing upon a subset of data from the Joint Asset Recovery Database (JARD) covering the years between 2003 and 2016. The first part of the article will outline briefly the key legislative provisions of asset recovery in the UK - the Proceeds of Crime Act (POCA) 2002 and the recent legislative changes introduced by the Serious Crime Act 2015 and the Criminal Finances Act 2017. It will then look at the JARD data and the literature to see what it tells us about the performance of the proceeds of crime approach. The article draws upon, and then expands the UK findings of EU funded research into organised crime (Wall and Chistyakova 2015; Wall and Bonino 2015; Wall, Chistyakova and Bonino 2016). The analysis and interpretation of the asset recovery data presented in this paper was assisted by in-depth but informal conversations with a senior law enforcement officer and with several lower ranking police officers (formal interviews were not possible for reasons of access and sensitivity).

\section{The UK Proceeds of Crime Act (POCA) 2002}

In the UK, the recovery of the proceeds of crime is, as indicated above, regulated by the Proceeds of Crime Act (POCA) 2002. The Act consolidates earlier provisions by bringing together two previously separate confiscation regimes (one for drug trafficking offences and one for other offences) and including several types of asset recovery, such as criminal confiscation, civil recovery, cash seizure and forfeiture, and taxation of criminal proceeds. It extended the confiscation powers to include financial crimes and empowered the courts to 
confiscate assets based on assumptions about the origins of the assets (explained further in this section). In addition, it introduced criminal offences relating to money laundering and promoted the establishment of the Asset Recovery Agency (ARA) in 2003. The ARA was absorbed into the Serious Organised Crime Agency (SOCA) in 2008 and the National Crime Agency (NCA) in 2013.

Confiscation orders are the main tool of asset recovery, which follows the conviction of offenders in criminal courts. The Proceeds of Crime Act 2002 allows the recovery of proceeds gained either from offences for which the offender was convicted, or from their general criminal conduct. The latter is possible if it is established that the offender has led a 'criminal lifestyle' that they would not have otherwise conducted that was based upon the proceeds of their crime. In criminal lifestyle cases, all of the offender's assets from the previous six years can be treated as assets from criminal conduct, unless the offender can prove otherwise. The value of a confiscation order will depend on two key variables: the amount of benefit from criminal conduct and the amount of assets available for confiscation - the smaller of the two amounts is used to calculate the order. The value of criminal benefit is calculated using the total revenues of the offender, not their net profits.

The National Audit Office (NAO) has undertaken two value for money evaluations of the administration of confiscation orders (NAO 2013, 2016) and identified several issues, including the absence of a coherent strategy and agreed success measures. A new Criminal Finances Improvement Plan established in 2014 set out 11 objectives against which progress was to be measured, including the enforcement and clearing stock of unenforced orders; maximising the use of financial investigation techniques to disrupt serious and organised criminals; strengthening the ability to recover assets hidden overseas, and ensuring that the asset recovery incentivisation scheme (ARIS) works. One of the issues found which continued to impede agencies' ability to recover assets was the underuse of restraint orders to freeze assets quickly enough before an offender hides, spends or disposes of criminal assets. The Serious Crime Act 2015 enhanced the provisions of the POCA 2002 to make it easier to apply for a restraint order in order to ensure quicker restraint and more effective confiscation, recovering more assets overall. The second NAO (2016) report concluded that progress was not as expected despite some improvements, such as stronger accountability of individual bodies, improved overall enforcement rates and better joint working across bodies. In particular, confiscation orders have not become a priority for law enforcement bodies and there was a reduction in the number of orders imposed, fewer financial investigators and fewer restraint orders. It was also unclear whether the stronger sanctions for non-payment of orders (e.g. longer default sentences) were successful. Other evaluations of the changes introduced by the Act concluded that some of the amendments lack a firm evidence base, including the lower burden of proof in the seeking of a restraint order and the use of longer default sentences for failing to meet the confiscation order (Wood 2016b).

In 2017, in the wake of the Panama Papers' revelations about the use of 'tax havens' to hide and launder illicit wealth, ${ }^{1}$ the Criminal Finances Act 2017 amended the POCA 2002, introducing further powers to improve confiscation; this includes unexplained wealth orders (UWOs), disclosure orders and enhanced civil recovery and forfeiture powers. Another amendment was the introduction of failure to prevent facilitation of tax evasion. It is important to note here that while this new legislation is a significant extension to the POCA 2002, the

\footnotetext{
${ }^{1}$ The Act was also inspired by the Magnitsky case. Magnitsky was a Russian lawyer found guilty of tax fraud who died in prison after revealing a large-scale fraud by Russian officials (BBC 2017).
} 
data that we analyse in this article relates to confiscations made before it took effect on 30 September 2017. Although, as of February 2018, no one had yet been prosecuted for the 'failure to prevent the facilitation of UK and foreign tax evasion' (Webb 2018; UK Parliament 2018), which remained the case a year later. Which means that the jurisprudence in this area is still largely untested (Vitou and Ottaway 2019).

\section{The Joint Asset Recovery Database (JARD)}

The data analysed in this article come from the JARD database, which is the central repository of information relating to seizures of the proceeds of crime by a number of authorities and institutional agencies. JARD is owned and controlled by the National Crime Agency (NCA) and its operational and sensitive contents do not make it available for consultation by the public. It records all restraint, confiscation, cash seizure and civil recovery orders made throughout the United Kingdom, together with brief details of the assets considered when making such orders (Crown Prosecution Service 2016). It has been argued that the JARD data allows 'the UK asset recovery community to map the developing efficiency of the confiscation and recovery process'. The data also show 'how well the UK agencies fulfil their roles within the confiscation and recovery process' and 'give a very broad sense of whether the UK's ability to take funds out of criminal enterprises is improving over time' (European Commission 2009: 71).

Two separate datasets from JARD are used in this research. The first covers the period between 2003 and 2013 and the second relates to the period between 2013 and 2016. The first dataset contains a breakdown of confiscation order gross receipts for the years 2003-04 to 2012-13. The receipts are broken down by type of crime and also the enforcing authority. The dataset also contains the total value of confiscation orders made that relate to these receipts for the years 2003-04 to 2012-13. The second dataset contains a breakdown of confiscation order receipts for the years 2013-14 to 2015-16. The receipts are broken down by type of crime and enforcing authority. The dataset also contains confiscation order amounts for the years 201314 to 2015-16. It also contains a breakdown of the confiscation order amounts by type of crime and enforcement authority. ${ }^{2}$

The next section will look at changes in the value of confiscation receipts over time; we will then examine the gap between confiscation orders and the amounts recovered; this is followed by an overview of trends in recoveries by type of crime; finally, we will consider agencies' performance in confiscating criminal assets.

\footnotetext{
${ }^{2}$ It is important to note some of the limitations of the available data upon our analysis. The first dataset (20032013) contained no breakdown of the value of confiscation orders that relate to confiscation receipts by type of crime and confiscating authority. In the second dataset (2013-2016), 'confiscation order amounts' were figures of a much higher order compared to the 'total value of orders made that relate to the receipts' in the first dataset (2003-2013) which might be due to a different method used to calculate these figures. Because the two datasets are not fully compatible, we had to exclude 'confiscation order amounts' for 2013-2016 from our analysis. We also had no access to a breakdown of confiscation orders and receipts by value of order/receipt and therefore could not calculate the percentage of recoveries made from orders of different value. Furthermore, we could not compare the receipts we analysed to the costs of enforcing the orders, but we were able to refer to other sources that made such comparisons. There were also a number of 'unknowns' in the dataset that we analysed, such as 'other authorities', 'other crimes/unknown', 'money laundering - other' and 'other frauds'.
} 


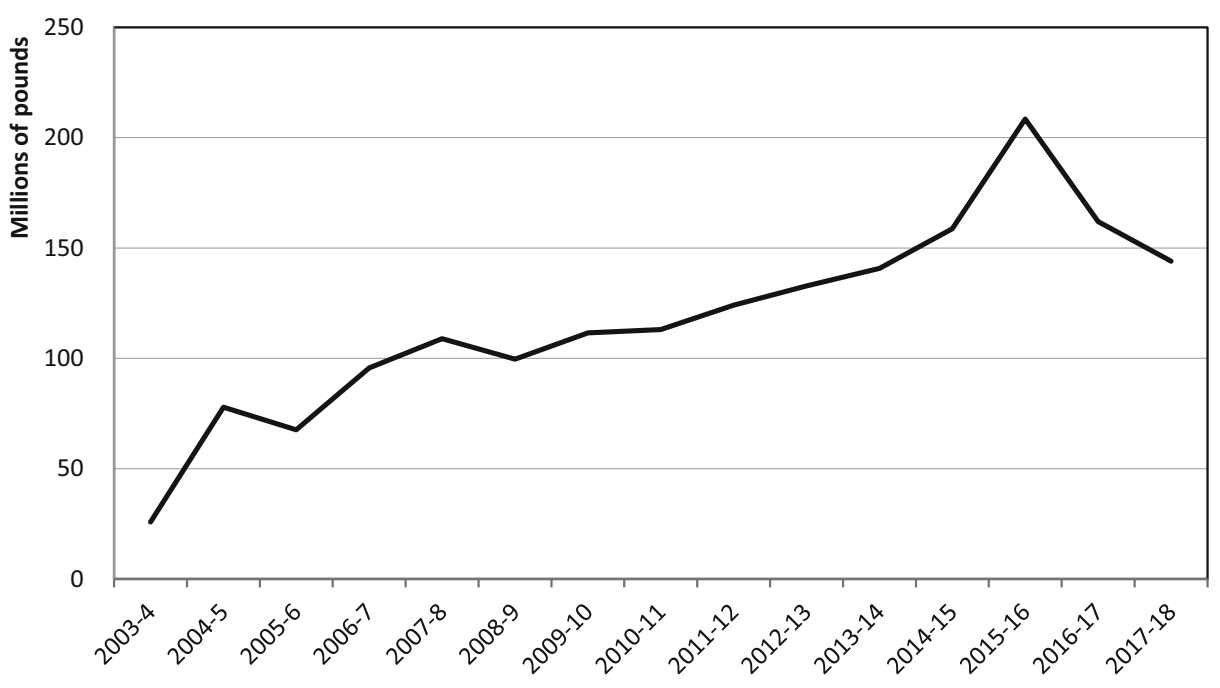

Fig. 1 Confiscation receipts totals 2003-18 (£m)

\section{Confiscation Receipts}

The value of confiscation receipts increased from $£ 25$ million in 2003-04 to about $£ 208$ million in 2015-16 - a more than eight-fold increase (Fig. $1^{3}$ ). The chart shows a clear overall upward trend between 2003-04 and 2015-16. Except for two dips, in 2004-05 (from $£ 78 \mathrm{~m}$ to $£ 68 \mathrm{~m}$ ) and in $2007-08$ (from $£ 109 \mathrm{~m}$ to $£ 100 \mathrm{~m}$ ), confiscation values increased every year and the growth in recoveries through confiscation orders accelerated between 2013 and 2016. The peak in collections achieved in 2015-16 ( $2208 \mathrm{~m}$ ), however, was due to several high value orders within that year and does not indicate a long-term trend (Home Office 2018). From 2016 onwards, there has been a reduction in assets collected from confiscation orders, from $£ 208 \mathrm{~m}$ in $2015-16$ to $£ 162 \mathrm{~m}$ in $2016-17$ and $£ 144 \mathrm{~m}$ in $2017-18$, probably reflecting the overall reduction in the number of orders made in this period. The value of recoveries remains modest, especially compared to the estimated size of the criminal economy (see NAO's estimates 2013; 2016); for example, the 2013 NAO report found that the actual amount confiscated in 2012-13 amounted to an estimated 26p in every $£ 100$ of criminal gains generated. However, the 13-year upward trend appears to be good news for asset recovery proponents. If the trend continues, eventually the regime may be able to achieve at least one of its objectives, significant revenue generation.

The rise in confiscations displayed in Fig. 1 (as explained by the senior law enforcement officer interviewed) reflects a growing awareness among the law enforcement agencies enforcing POCA 2002 and an increasing confidence in its use. This means, among other things, that the practitioners are becoming convinced that the confiscation of assets is not just about securing convictions but can also be used as a tool for disrupting criminal activities. The senior law enforcement officer further commented that it was the result of the NCA 'selling to law enforcement what POCA is about' and possibly also reflects the 'greed of incentivisation'. That is, the share of recovered assets going to the recovering agencies. An additional factor

\footnotetext{
${ }^{3}$ The last two numbers in the graph (2016-17 and 2017-18) were not part of the original dataset and were taken from the Home Office statistical bulletin published in September 2018 (Home Office 2018: 7).
} 


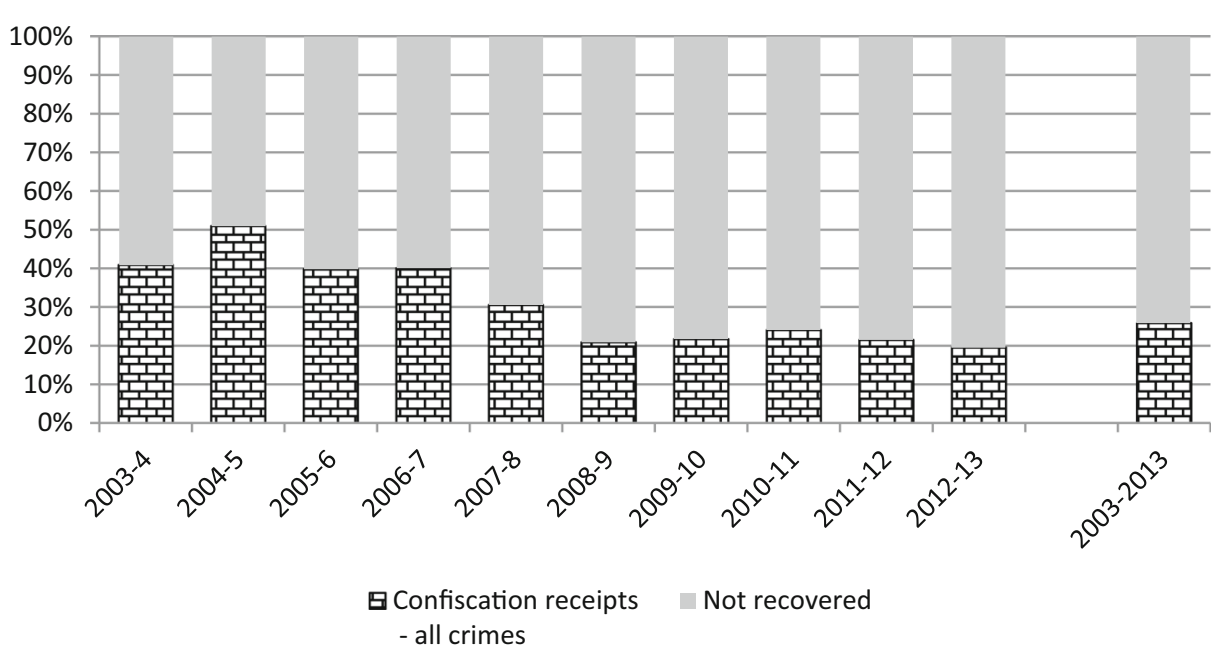

Fig. 2 Confiscation receipts 2003-2013 (\% of value of orders made)

worth mentioning is the downward trend in central policing funding from 2010/11, which may have provided an additional incentive for the police to focus on asset recovery.

The above data, of course, cannot be interpreted as a prima facie evidence of the regime achieving or not achieving its deterrence, disruption or symbolic objectives. The National Audit Office (NAO) assessment cited earlier focused solely on the values recovered and by this measure, progress has been steady, but very slow. This also does not tell us anything about other effects that the confiscations, even of low value, may have had, such as a deterrent or disruptive impact on offending or helping to reinforce the message that 'crime does not pay' (Bullock et al. 2009). Moreover, it tells us little about the potential unintended effects of the confiscation powers, especially as there appears to have been a drive to expand the law largely for political and ideological reasons. As a consequence, the low recovery figures were cited as evidence to justify the need for enhanced asset recovery powers (see e.g. NAO 2013, 2016), but the reforms were not arguably based on a clear understanding of how the powers work (see further: Levi and Reuter 2006; Harvey and Lau 2008).

\section{The Gap Between Confiscation Orders and the Amounts Recovered}

The second chart (Fig. 2) shows that the relative value of 'successful' confiscations (confiscation receipts in relation to the value of confiscation orders) has decreased over time. ${ }^{4}$ The declining enforcement rates can be explained by increases in attrition (the gap between the criminal benefit assessed and the value of confiscation orders imposed). Attrition 'varies between $£ 80 \mathrm{~m}$ and $£ 170 \mathrm{~m}$ each year' (HM Government 2013: 35). Only a limited number of high value orders are fully paid. A study by Bullock and Lister (2014) showed that while orders between $£ 10$ and $£ 10,000$ were paid in $80 \%$ of the cases, orders between $£ 10,000$ and

\footnotetext{
${ }^{4}$ Only 2003-13 data was used in Fig. 2 because 'confiscation order amounts' from 2013 to 16 dataset were not compatible with 'confiscation orders made that relate to these receipts' in the 2003-13 dataset.
} 
$£ 100,000$ were only paid in $60 \%$ of cases and orders between $£ 100,000$ and $£ 1$ million in $35 \%$ of cases (Bullock and Lister 2014). The stock of unenforced confiscation orders in 2017 was $£ 1.8$ bn and continued to rise (HMCTS 2017).

The main reason for attrition is the tendency to overestimate the value of recoverable assets by misconstruing the values of criminal benefit and the amounts of proceeds available from 'criminal lifestyle' assessment (see Bullock et al. 2009; Bullock 2014; Bullock and Lister 2014; see also: Levi and Osofsky 1995; Levi 2014). Commentators note that the framing and complexity of the law, as well as the relationship between the law and the practice of its implementation are largely responsible for the overestimation of criminal gains (Wood 2016a; Bullock 2014) and unrecoverable orders being set. In 'criminal lifestyle' cases, all of the defendant's property, income or expenditure can be treated as benefit from criminal conduct regardless of the actual origin of the assets, unless the defendant can prove otherwise on the balance of probabilities. Therefore, behind the gap between the amount set in confiscation orders and the values recovered is the operational discretion used by police and financial investigators to negotiate 'up' and agree inflated values of orders to try to maximise the benefit figure (see Bullock 2014 for a detailed analysis of this process).

Unsurprisingly, the enforcement of confiscation orders is far from straightforward given the tendency to make very broad assumptions about the value of criminal assets. To start with, some of the sums counted as 'proceeds' may have never existed. In drugs cases, for example, the actual street value of the drugs may be much lower than the value estimated by the financial investigators. Or, those estimates could be meaningless because the drugs could not be legitimately realised (see Bullock 2014), or if they do exist, they could be out of reach of law enforcement because the offender may have hidden the assets abroad, or the assets may not be in their name. In such cases, the law relies on the willingness of offenders to acknowledge and pay the order in full, which presents difficulties in cases where the offender is either absent or unwilling to do so, for example, hidden assets; defendants absconding, dying or being deported; and general difficulties in realising inelastic assets (Bullock et al. 2009: 9; Wood 2016a). A restraint order can help prevent dissipation of assets (Bullock et al. 2009), but prosecution may sometimes be unable to demonstrate that there are 'reasonable grounds to believe ${ }^{5}$ that the alleged offender benefited from criminal conduct and that their business is illegal. The senior law enforcement officer working on POCA, informally interviewed for this research also commented on the general lack of awareness and knowledge of the law and the reluctance of judges and prosecutors to apply the confiscation provisions of POCA 2002. He commented that it is important 'to educate confiscators so [that] they look at what is realistically achievable'. Insufficient incentives to enforce orders have also been seen as a factor inhibiting enforcement (Bristow; 2014; Sedwill 2014; see also: Levi and Osofsky 1995; Wood 2016a). Improved knowledge of the law and better incentives, such as more powerful enforcement tools may be able to help enforce confiscation orders, but they will not be of much help in cases where the values of criminal benefit were poorly estimated or created artificially. Even cases where 'hidden assets' are assumed to be 'hidden' overseas may have already be spent or may have never existed (Wood 2016a). The fact that unrecoverable assets play a significant part in the construction of the value of confiscation order means that the percentage of enforced confiscation orders is a misleading measure of performance of the proceeds of crime approach (see also Wood 2016a, 2016b). The Crown Prosecution Service admitted in its 2014 Asset Recovery Strategy that 'the value of a confiscation is not always a

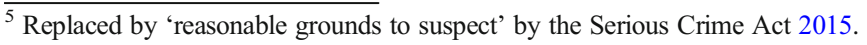


Source: adapted with permission from Transcrime, Savona EU and Riccardi M (eds.), (2015) From illegal markets to legitimate businesses: the portfolio of organised crime in EU

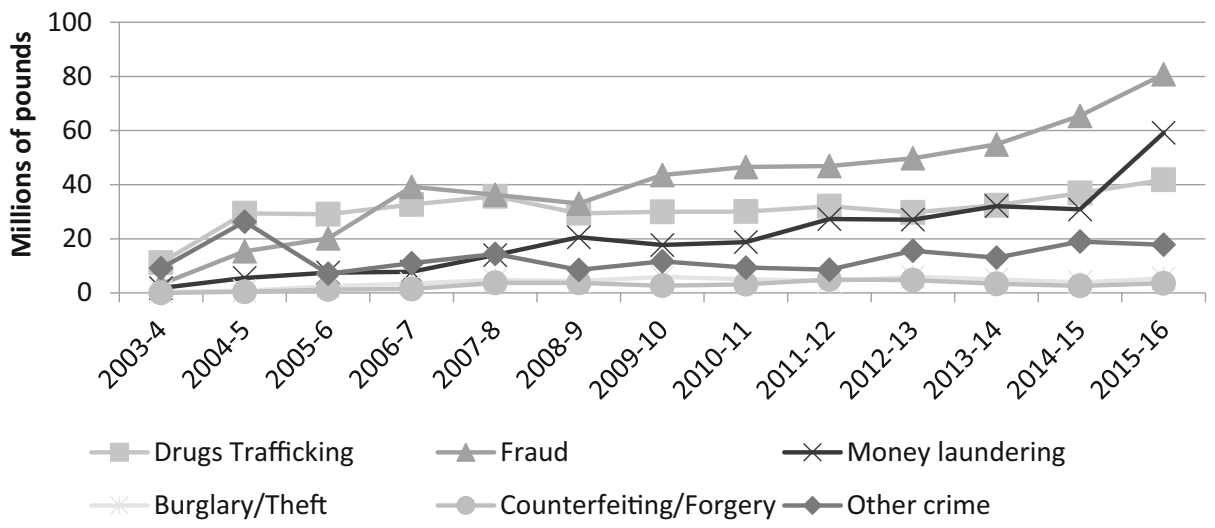

Fig. 3 Values of confiscation receipts by type of offence 2003-16 (£m)

true measure of the amount that is actually recoverable' (Crown Prosecution Service 2014: 6). One of the law enforcement officers we interviewed commented that the Home Office has been trying to improve the enforcement of confiscation orders by 'reviewing high-value confiscation orders to see which ones are realistically achievable'.

\section{Trends in Recoveries by Type of Crime}

This section breaks down confiscation receipts by type of offence. Offences were clustered into six main categories: 'drug trafficking', 'fraud', 'money laundering, 7 'burglary/theft', 'counterfeiting/forgery' and 'other crime/unknown'. ${ }^{8}$ As shown in Fig. 3, such areas as drug trafficking, frauds and money laundering are the offences that 'provide' recovery agencies with the most assets recovered. Drug trafficking is the largest 'source' of assets. This finding is consistent with data from other sources (see, for example: Bullock et al. 2009; Harvey and Lau 2008; Harvey 2014; Wall and Chistyakova 2015).

The JARD data reveal a clear trend over the ten-year period towards more confiscations originating from fraud and money laundering, and some decline in confiscations from drug offences. The confiscation from drug trafficking spiked between 2003-04 and 2004-05 and then fluctuated between $£ 29-35$ million throughout the subsequent nine years, with a further increase from 2013 to nearly $£ 41$ million in 2016 (Fig. 3). The confiscation of assets from frauds consistently increased from $£ 3$ million in 2003-04 to $£ 15$ million the following year and in 2006-07 exceeded drugs as the main yield. By 2015-2016, fraud confiscations (at £81 million) doubled those from drugs. The confiscation of assets from money laundering fluctuated, but the 13-year trend is also clearly

\footnotetext{
$\overline{6}$ This includes 'tax/benefit fraud', 'VAT fraud', 'excise duty fraud' and 'other fraud/embezzlement'.

7 This includes 'money laundering - drugs' and 'money laundering - other'.

8 This includes 'other crime/unknown' and all the crime categories that contribute to $1 \%$ or less towards the total confiscation, that is 'handling stolen goods', 'pimps/brothels/prostitution/pornography', 'people trafficking', 'intellectual property crime', 'vehicle offences', 'robbery', 'arms trafficking', 'bribery and corruption', 'trading standards' and 'terrorism'.
} 
upward. There is a particularly sharp increase in 2015-16 from $£ 31$ million in the previous year to $£ 60$ million, nearly doubling the value recovered from money laundering offences. The other three crime categories either registered an increase (burglary/theft and counterfeiting/forgery) or fluctuated considerably (other crime/unknown).

Further in this section we take a closer look at frauds and money laundering and the possible explanations behind the increase in recoveries from these offences over time. The trend towards more confiscations from frauds and money laundering reflects changing political priorities and legislation, in particular, increased interest in the UK and across the European Union in pursuing 'dirty money' and the increasing use of the proceeds of crime law against fraud and money laundering. The main drivers of this new focus on criminal finances has been the perceived convergence 'of numerous alleged threats such as organised crime, money laundering, drugs and terrorism (and terrorism financing)' (Hobbs and Antonopoulos 2013: 43) and the view that greater financial transparency and control are a key tool in countering terrorism (Levi and Reuter 2006). ${ }^{9}$ The key legislative provisions include, firstly, the third European Directive on Money Laundering ${ }^{10}$ and related obligations and increased powers given to authorities to tackle those crimes; and secondly, the Fraud Act $2006^{11}$ and the Money Laundering Regulations 2007, ${ }^{12}$ the enactment of two Directives to tackle VAT-fraud and other types of fraud in 2013. This has been coupled with new European research on the topic (CSD 2015), which calls for an increase in money laundering investigations and greater emphasis on organised crime finances across European countries (Hicks 2015). In the UK, the new strategy emphasised by the Home Secretary, according to the senior law enforcement officer interviewed, were financial strategies in relation to priority organised crime groups. Among them, the interviewee referred to immigrants from former Eastern European countries involved in organised crime, sex trade and illegal money sent to the UK from China. ${ }^{13}$

More specifically, the Fraud Act 2006 created a number of new offences of fraud and expanded the scope of activities that can be prosecuted in order to deal with financial offences, while the Money Laundering Regulations 2007 obliged businesses to make Suspicious Activity Reports (SARs) to detect money laundering, enabling greater use of restraint orders. Levi and Maguire (2004) note the pressure exerted by supranational and national bodies to increase the number and range of these reports despite the absence of robust scientific evidence of their impact. For example,

\footnotetext{
${ }^{9}$ Other authors, however, such as Bonino (2012), have argued that financial measures alone (especially financial disruption) are insufficient to effectively tackle terrorism and that, instead, the removal of human capital and ideological support for terrorist groups should be the top counter-terrorism priorities.

${ }^{10}$ Directive 2005/60/EC of the European Parliament and of the Council of 26 October 2005 on the prevention of the use of the financial system for the purpose of money laundering and terrorist financing broadened the scope of anti-money laundering provisions and placed an obligation upon the financial, credit and other institutions and professionals regulated by the directive to report suspicious financial transactions.

${ }^{11}$ The Fraud Act introduced such offences as "fraud by misrepresentation", "fraud by failing to disclose information" and "fraud by abuse of position", replacing several deception offences with a single offence of fraud. It also created offences for making or possessing articles for use in or in connection with fraud and making or supplying articles for use in fraud (Crown Prosecution Service 2016).

${ }^{12}$ Money Laundering Regulations 2007 is secondary legislation supplementing the POCA anti-moneylaundering provisions and implementing the provisions of the third EU Money Laundering Directive in the UK. POCA Part 7 contains provisions concerned with dealing with criminal property and requires institutions in the regulated sector to disclose any suspicions concerning criminal property. A nominated officer submits Suspicious Activity Reports (SARs) to the Financial Intelligence Unit (FIU) containing information about the individual and the transaction which then goes to law enforcement.

${ }^{13}$ At the time of the interview, July 2014.
} 
220,484 SARs were received in 2007-08; almost 50\% more (that is 316,527) in 2012-13; 381,882 (58\% more) in 2014-15; and 419,451 in 2015-16 (National Crime Agency 2013, 2015, 2017). More agencies are now trained and empowered to deal with fraud and money laundering and more accredited financial investigators now work in police forces and Regional Asset Recovery Teams (RARTs). ${ }^{14}$ In addition, the senior law enforcement officer interviewed identified some other factors as contributing to increased recoveries from fraud, such as frauds becoming part of the Home Office statistics and new agencies dealing with fraud. The National Trading Standards Regional Investigations Teams work across England and Wales to target doorstep crime, counterfeiting, consumer and business fraud and local Councils are now 'more alert' to frauds and run various 'scam buster teams'. Plus, there is more joint counter-fraud work taking place, for example, Crown Prosecution lawyers dealing with POCA 2002 related matters now work in Regional Asset Recovery Teams. With regards to money laundering, the senior law enforcement officer pointed out that more proceeds are being seized because of the growing awareness of money laundering within the Crown Prosecution Service and its ability to use the legislation to charge more individuals for money laundering offences.

Looking back at Figure 3, it is hardly surprising that recoveries are mostly from drug trafficking and fraud offences. According to estimates, drugs and frauds are the most profitable illicit markets in the UK and the EU (Wall and Chistyakova 2015; Savona and Riccardi 2015). The intention of the Home Office and the NCA has been, according to our interviewee, to use the law as a disruptive tool and prioritise 'those who create greater harm'. The question is, however, whether the increase in confiscations reflect successes of the regime in targeting the intended offences - serious and organised fraud and money laundering linked to organised crime. One of the main objectives of the law was to target proceeds from serious crime to disrupt criminal enterprises and deprive criminals of capital, so that they are unable to invest in further offences that can damage the economy and harm society. However, given the relatively modest sums recovered from fraud and drug offences, it is quite likely that a significant proportion of these offences are not high-level corporate fraud or organised crime but lower level illicit activities. Bullock et al.' (2009) analysis revealed that mean order value for drugs trafficking was approximately $£ 20,000$. For fraud/deception offences the figure was $£ 51,000$. This suggests that many of the fraud recoveries may have been not from organised professional/career or corporate criminals but from relatively low level or one-off fraudulent acts and even include benefit claimants. The UK National Fraud Initiative ${ }^{15}$ is arguably a key factor in encouraging agencies to focus upon low-level volume frauds, such as pension fraud, overpayments, welfare benefit fraud and council tax discount payments (Richards 2016). A similar conclusion can be reached if one looks at the annual number of prosecutions for serious fraud, tax and benefit fraud offences. The UK Serious Fraud Office prosecutes 20 individuals per year, and around 400 are prosecuted for tax offences, but there are 10,000 benefit fraud prosecutions annually (Whyte and Wiegratz 2016: 239). Thus, while frauds are a high priority for asset recovery agencies, the frauds that are targeted are not necessarily those that should be prioritised (e.g. not serious, high value fraud offences). In comparison, according to the JARD data analysed, bribery and corruption activities appear to be a very low priority, with no

\footnotetext{
${ }^{14}$ There was, however, a reduction in the number of accredited financial investigators between 2013 and 2016 (NAO 2016: 4).

${ }^{15}$ National Fraud Initiative, https://www.gov.uk/government/collections/national-fraud-initiative
} 
recoveries at all made until 2011-12, and overall recoveries from bribery/corruption being just $0.2 \%$ of total recoveries in 2003-13 (compared to $15 \%$ recovered from tax/benefit fraud). ${ }^{16}$ There was some increase in recoveries from bribery/corruption in 2014-15 and 2015-16, but these sums were still below $1 \%$ of the total recoveries made during these years. Thus, corruption and bribery were not prioritised during this period compared with benefit fraud, despite the very small scale of the latter - just $2.1 \%$ of total benefit expenditure was overpaid due to fraud and error in 2017-18 (GOV.UK 2018).

As noted earlier, money laundering is another priority for the POCA 2002. It is categorised as a 'lifestyle' offence and is prioritised because of the potential links to terrorism and other serious and organised crime. Meaningful measurement in this field is, however, very difficult (Levi and Maguire 2004). Money laundering has been characterised as a confusing and ever-growing offence (Harvey and Lau 2008) and a 'mystifying and glamorising' rhetorical tool that makes the predicate offence part of the security agenda (Alldridge 2016: 72). Almost anything an offender does with illicit assets can be categorised as 'laundering' which amplifies the problem and helps agencies present the problem of 'dirty money' as important and growing and claim more resources and powers (Alldridge and Mumford 2005: 373; Levi 2016: 2). Thus, its main value is that it (arguably) legitimises new anti-laundering and asset recovery activities and definitions can always be expanded to increase the amount of money that can be treated as laundering. ${ }^{17}$ As the senior law enforcement officer interviewed commented, 'you do not have to have a theft, if there are suspicious circumstances, then this is what is going on, money laundering'. As antilaundering activities expand, more laundering is discovered, and 'the entire industry can become self-authenticating' (Alldridge and Mumford 2005: 373). This is demonstrated by the expansion of the anti-money laundering industry from drugs to other areas such as organised crime, terrorism, corruption and tax (Alldridge 2017). For example, if certain offences are categorised as 'tax evasion', the overall turnover of a business can then be treated as the criminal property, not just the unpaid tax (Alldridge 2017). Once tax evasion can be treated as a predicate offence, it is possible to treat any undeclared income as money laundering; it is easier to prove that someone has not declared income for tax purposes, rather than having to prove that the money came from a specific drug dealing offence, explains Alldridge (2017: 167). This may explain why confiscations from money laundering offences grew faster than confiscations from drug offences (see Fig. 3).

\section{Agencies' Performance - A Growing Asset Recovery Industry?}

Figure 4 shows that police are the main contributor to confiscations, recovering between 39 and $59 \%$ of the total value.

The central role of the police in asset recovery is explained mainly by the fact that they are responsible for the majority of confiscation orders. According to the NAO it is nearly $90 \%$ of all orders (HM Treasury and Home Office 2015: 23; NAO 2016: 18). This may, however, also reflect the impact of the Asset Recovery Incentivisation Scheme that has encouraged the collection of assets by police forces, the growing familiarity of police forces with the

\footnotetext{
${ }^{16}$ The data for bribery/corruption is not included in Fig. 3 due to very low numbers.

${ }^{17}$ For example, in England and Wales tax offences are treated as predicates to laundering since 2005 (Alldridge 2017).
} 


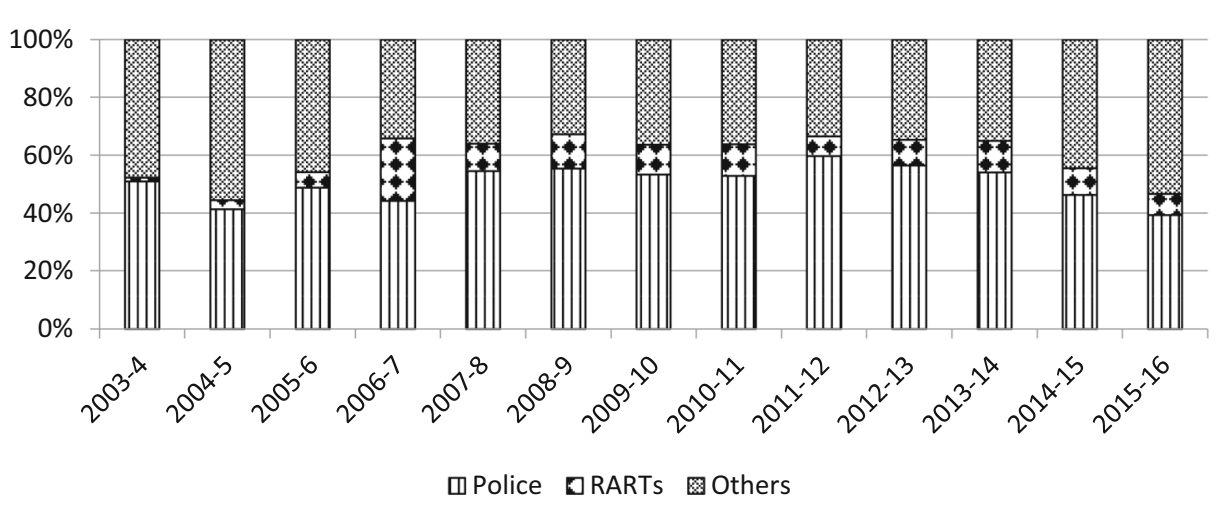

Fig. 4 Relative contributions by the police, RARTs and other agenices to total confiscation 2003-16 (\%)

legislation and more accredited financial investigators being appointed in forces to work on asset recovery. The police officers, who were informally interviewed as part of this research, argued that incentivisation money was important to them. The officers were involved in the investigation of a cash for crash case, with the estimated benefit from the illicit business of over $£ 3 \mathrm{~m}$, and part of the $£ 155,000$ confiscation order money paid and reinvested back to the police and the Home Office.

The yearly trend (Fig. 5) shows that the reinvestment in the police from seized assets maintained an upward trend until 2011-12, but declined between 2012-13 and 2015-16. The Regional Asset Recovery Teams ${ }^{18}$ recovered between 1 and $21 \%$, achieving their maximum yield in 2006-07. RARTs' yields increased between 2003-04 and 2006-07, achieving their maximum in 2006-07, but dropped in the following year and remained at around 7-11\% since then. Other partner agencies, ${ }^{19}$ and local authorities, account for between 33 and $55 \%$ of all recovered assets. The yield of these agencies increased between 2003-04 and 2004-05 and then declined between 2004-05 and 2011-12, increasing again between 2012-13 and 2015-16. Taken together, it reached $55 \%$ of the overall sum in 2015-16. Overall, Fig. 5 shows that from 2014-15 the overall yield from other agencies exceeded the police yield and grew faster. Data on the HMRC and Home Office/UKBA yields for 2013-14, 2014-15 and 2015-16 (not displayed on the graphs) showed that the HMRC yield was quite significant at $16 \%$ of the overall value recovered in 2013-14 and then declined to $11 \%$ in 2015-16, while the Home Office/UKBA's yield remained very low at less than $1 \%$. HMCTS recently reported that ' 39 per cent of confiscation orders by value are enforced by agencies other than HM Courts \& Tribunals Service, including the CPS, SFO, Department for Work and Pensions and local authorities' (HMCTS 2017: 5). This means that any one or more of these agencies could contribute to the overall upward trend. RARTs represent joint work between several agencies

\footnotetext{
${ }_{18}$ The teams were established in 2004 in five Association of Chief Police Officers (ACPO) regions (England and Wales) initially with the aim of maximising asset recovery. They are made up of experts from police forces and other agencies, such as Trading Standards; HMRC; UKBA; SCOA; DWP; Environment Agency and Local Authorities.

${ }^{19}$ Which include Her Majesty's Revenue and Customs (HMRC), Her Majesty's Courts and Tribunals Service (HMCTS), Crown Prosecution Service (CPS), Public Prosecution Service for Northern Ireland (PPSNI), Northern Ireland Courts and Tribunals Service (NICTS), the Department for Work and Pensions (DWP), the National Crime Agency (NCA), the Serious Fraud Office (SFO), the UK Border Agency (now UK Visas and Immigration - UKVI) and possibly other agencies.
} 


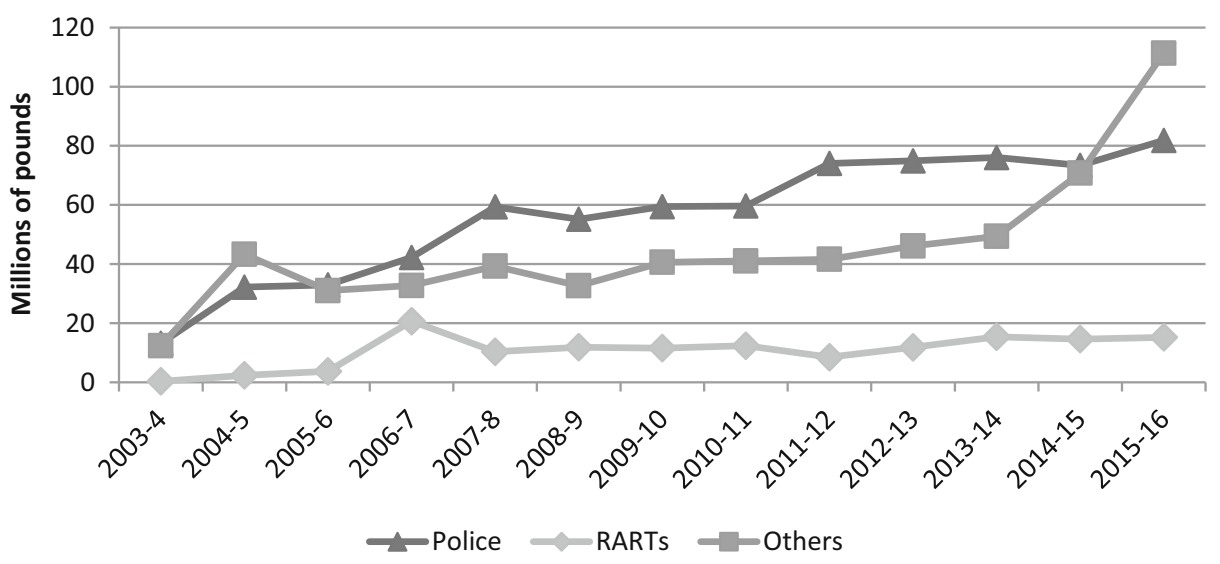

Fig. 5 Trends in contributions by the police, RARTs and other agencies to confiscation 2003-16 (£m)

(police, CPS, HMRC), and their yield has remained relatively modest, suggesting that this teamwork approach remained a relatively low priority.

Incentivisation appears to be one of the factors behind the differences in the agencies' recoveries. Half of the criminal proceeds that are derived from confiscation orders go to the Home Office and the other half go to the bodies involved in recovery and are divided in a three-way fashion among them, with investigation and prosecution receiving $18.75 \%$ each and enforcement receiving $12.5 \%$. In cash seizure/forfeiture cases the asset recovery body retains 50\% of the cash (NAO 2013). Therefore, seizures of large sums of cash are more greatly rewarded, but the rewards do not necessarily reflect agencies' contribution to asset denial or crime disruption. Since 2014, some improvements to the incentivisation scheme have been made by the Home Office, such as clearer reporting on how the monies are used (NAO 2013, 2016). However, it is unclear whether this has encouraged behaviours that best meet asset denial or crime disruption objectives.

Other possible explanations for the differences between the agencies are different performance targets and the fact that different agencies deal with different types of offences and may be presented with more or fewer opportunities to confiscate assets (NAO 2013, 2016). Furthermore, the NAO (2016: 17) notes the following factors affecting the use of confiscation orders by agencies: the low priority of confiscation orders within many enforcement agencies; the lack of knowledge of proceeds of crime legislation; the lack of consistent selection of cases; and the length of time and amount of resources needed to develop cases - reflecting the findings in other POCA fields (see earlier). Also, the differences in statistics between different agencies may also be in part a reflection of the different ways that they enter the data into the database, particularly where two or more agencies are involved in investigation, prosecution and enforcement of orders (for example, HMRC and DWP working together, see also Harvey and Lau 2008). All the above means that the breakdown of confiscation data by agency is not a straightforward measure of individual agency performance. More importantly, the differences the data reveal suggest that it is important to understand what the agencies think about confiscation and their own role within it; the assumptions that they make when selecting cases and their understanding of the importance, value, means and ends of confiscation. In particular, it is important to understand whether and where the agencies see the value of confiscation beyond the monetary value of recovered assets, and to what extent they see the deterrent and disruptive potential of asset recovery from where they stand. 
There is a growing number of agencies involved in the confiscation process, and ongoing effort is made by the State to enhance coordination between the different agencies. The regional asset confiscation teams (ACE) and the Multi-Agency Enforcement group created in 2014, for example, are chaired by the NCA and attended by the CPS, HMCTS, the Regional Asset Recovery Teams and others (Wood 2016b). The Joint Money Laundering Intelligence Taskforce, led by the NCA includes representatives from the financial sector, the Financial Conduct Authority, HMRC and the Home Office (House of Commons Home Affairs Committee 2016). There are also plans to enhance cooperation with the private sector on asset recovery. The effects of the recent initiatives on asset recovery remain to be seen. It is important to understand how the new institutional landscape and the array of agencies constituting the asset recovery 'community', equipped with new powers and capacities, will shape the policy and practice of confiscation.

\section{Income Collection}

As we have seen from the previous sections, while income collection has improved, the current figures are still a very small fraction of the estimated illicit wealth in circulation, although the latter itself has been challenged (see, for example, Naylor 1999). From that point of view, unexplained wealth and tax evasion, particularly offshore evasion, may still prove to be the most promising routes to increasing revenue from asset recovery. According to some estimates, upwards of 500 billion dollars is transferred by multinationals to tax havens each year (Tax Justice Network 2017; Zucman 2017). As with other proceeds of crime provisions, the jurisprudence around unexplained wealth orders (colloquially known as McMafia Laws) is relatively untested, but cases, such as that of Zamira Hajiyeva, the wife of a jailed banker who was ordered to show how she funded her extravagant lifestyle are beginning to work their way through the courts (Sky 2019; Magra 2019).

As far as tax evasion is concerned, while the UK government claimed in 2017 to have secured nearly $£ 160$ bn since 2010 thanks to its tax compliance activities, the 'gains' from such activities are arguably difficult to measure (O’Leary 2017). Some, for example, Kitchener (2017), have questioned the ability of governments to reach the money hidden offshore as those using the Offshore Financial Centres for both illegal, legal or ethically questionable investments are able to avoid detection easily. It is arguable that small businesses will actually bear the brunt of any government crackdown on tax evasion because they are easier targets; bigger economic players, both legal and illegal, tend to pay smaller price (Andrew 2013). In particular, the wealthier and more powerful actors (both legal and illegal) can employ financial experts to hide their money by exploiting legal loopholes and tax havens (Box 1983). In so doing, they may be able to get help from the banking sector (Burgis 2016) and if they are senior corporate actors they are less likely to be suspected of being involved in fraud or money laundering (Levi 2015). It is also more difficult for governments to go after bigger illegal players as the interests and finances of the latter are often closely intertwined with the interests of elites and big legal business (see Antonopoulos and Hall 2016; Ruggiero et al. 1998 cited in Antonopoulos and Hall 2016: 715; van Duyne 2003 cited in Antonopoulos and Hall 2016: 715).

While illicit wealth may be a reputational concern for governments, it is not clear how committed they are to target super-rich offenders. Between 2008 and 2015, under the Tier 1 Investment Scheme, individuals, who invested $£ 10$ million or so in the UK could apply for permanent residence within 2 years of entry. Many of the investments made during this period by Russian oligarchs in London properties allegedly have dubious origins and possible links to organised crime (Staunton 
2018). A view expressed recently by the former National Police Chiefs' Council's lead for serious and organised crime and lead officer for the National Crime Agency is that the real value of unexplained wealth orders is in enabling police forces to go after 'ordinary' low level criminals (Sims 2019). If this is a view broadly shared by governmental agencies, then UWO (unexplained wealth order) powers are likely to be streamlined and used primarily against low-level offences, in a similar way to the use of confiscation orders utilised so far.

\section{Conclusions}

This paper contributes to ongoing debates about the value of the confiscation of proceeds of crime approach by reviewing the current literature as well as examining a subset of JARD data to see what the evidence can demonstrate about the performance of the regime. The data we examined suggest that, in practice, seizing illicit wealth has not been the main priority for the government, rather, the POCA 2002, originally designed to target serious and organised crime, has been streamlined to be used predominantly as a disciplining and symbolic tool against relatively lowlevel acquisitive crimes. There is, however, little evidence to say whether it has been effective against the most harmful criminal enterprises and networks. Currently, evidence of deterrent, disrupting or harm-reduction impact of asset recovery and anti-money laundering measures on criminal markets, especially in relation to organised crime and terrorism, remains weak (Levi 2003, 2013; Alldridge 2003; Levi and Maguire 2004; Gallant 2005, 2014; Levi and Reuter 2006; Harvey and Lau 2008; Sproat 2009; Goldsmith et al. 2014; NAO. 2016; Atkinson et al. 2017). Individual agencies use a range of internal measures of impact, but these approaches cannot isolate the impact of specific measures such as confiscation orders (NAO 2016: 37). Some critics argue that better metrics are needed in order to be able to assess and compare asset recovery with other methods of disruption (Stott 2014: 30; Creedon 2014: 8). Socio-metric analysis, however, offers no insights into how offenders operate, respond and adapt to regulation (Hobbs 2014; Levi and Reuter 2006; see also Antonopoulos and Hall 2016; Trainor 2017; Wood 2016b).

The ever-increasing reach of the law continues to be based upon questionable evidence of impact at best. Moreover, our discussion suggests that the imprecise nature of categories used in the JARD system, such as money laundering, enables almost any asset to be recorded as 'laundering'. This means that probably any data in the areas of drugs or organised crime should not be taken at face value.

While better measures of impact may remain an elusive target, there are more fundamental issues that need to be considered. The issue of confiscating proceeds of crime has often been discussed in narrow 'what works' terms and government agencies have been primarily concerned with technical implementation issues, such as improving awareness, skills, knowledge and expertise of the confiscators, broadening the range of the confiscating agencies, strengthening cooperation, enhancing their ability to recover assets and improving data and evidence gathering techniques, whereas, by comparison, the ideological and normative foundations of the proceeds approach have received relatively little attention. Major questions still remain unanswered, such as what counts as proceeds of crime and upon what criteria does it count? How far should State powers of confiscation be able to reach into individuals' financial affairs or to challenge private property rights, and what crimes, offender groups or harms should confiscating agencies prioritise? The meaning and scope of the confiscation of proceeds of crime has also frequently changed following shifting understandings of criminal threats, from drugs to terrorism, organised crime, money laundering and unexplained wealth. However, the political underpinnings of these processes have not been subject to a thorough and critical analysis. The ideological assumptions behind the prioritisation of particular threats, 
groups and criminal activities often remain implicit. Although hard to prove conclusively, asset recovery thus seems to bear little relation to the social harm caused by the offences that generate illicit proceeds. Instead, the recovery agencies appear, from the data, to focus upon 'easy targets', the 'low hanging fruit'. Which supports the argument often made in critical criminological literature that the less powerful typically find themselves on the receiving end of the process of law enforcement, while the wealthier and privileged are better able to evade punishment and criminalisation (see, e.g., Box 1983; Reiman 1979; Whyte and Wiegratz 2016).

The questions about the meaning of the proceeds of crime and the legitimacy of confiscation powers are clearly broader than the question of how to use asset recovery to disrupt specific illegal activities. It is also important to remember the symbolic messages that laws such as the POCA 2002 send to society and which indicate the directions of State intent. It may be sensible for nation states to pursue a strategy of containment in relation to organised crime (Levi and Maguire 2004) or other threats, and some would argue that the proceeds of crime approach is an important component of the arsenal of criminal and civil justice tools that can be used as part of this strategy. It is important, however, to subject the proceeds of crime discourses and claims to critical scrutiny, in terms of the State's priorities in pursuing these proceeds and the meaning attached to 'proceeds of crime' in legislation and in practice. This should include questioning dominant understandings of illegal and illegitimate wealth and the ways in which the State should be involved in recovery and (re)distribution of this wealth and of the social ends that this process should serve. From this vantage point, it is hoped that the value, prospects and limitations of the proceeds of crime approach will become clearer.

Acknowledgements Our thanks go to the team at Transcrime (Catholic University, Italy) and to the various European partners on the OCP (Organised Crime Portfolio) and ARIEL (Assessing the Risk of the Infiltration of Organized Crime in EU MSs Legitimate Economies: a Pilot Project in 5 EU Countries) projects (see Savona and Riccardi 2015 and Savona and Berlusconi 2015). Also thanks to Liz Campbell, Niall Hamilton-Smith, Stuart Hyde and Paolo Campana for their help with this article. We would like to thank the National Crime Agency (NCA) for help with access to the data and also to the various police officers who informally helped us with the research. We must emphasise that the interpretation of the data is ours and not that of the NCA or the other policing agencies which also assisted. Finally, we would like to thank the two anonymous reviewers for their suggestions and comments.

Funding This work was supported by two EU FP7 funded projects; the Organised Crime Portfolio (OCP) [HOME/2011/ISEC/AG/FINEC/400000222] and ARIEL [HOME/2012/ISEC/FP/C1/4000003801] and is informing [Horizon 2020/700688] Understanding the Dimensions of Organised Crime and Terrorist Networks (TAKEDOWN).

Open Access This article is distributed under the terms of the Creative Commons Attribution 4.0 International License (http://creativecommons.org/licenses/by/4.0/), which permits unrestricted use, distribution, and reproduction in any medium, provided you give appropriate credit to the original author(s) and the source, provide a link to the Creative Commons license, and indicate if changes were made.

\section{References}

Abadinsky, H. (2003). Organized Crime (7th ed.). Belmont: Wadsworth/Thomson.

Albanese, J. (1996). Organized Crime in America (3rd ed.). Cincinnati: Anderson.

Alldridge, P. (2003). Money Laundering Law. Oxford: Hart.

Alldridge, P. (2016). What Went Wrong with Money Laundering Law? London: Palgrave.

Alldridge, P. (2017). Tax, Money Laundering and Offshore: the HSBC Suisse Affair. In K. Ligeti \& M. Simonato (Eds.), Chasing Criminal Money: Challenges and Perspectives On Asset Recovery in the EU. Oxford: Hart. 
Alldridge, P., \& Mumford, A. (2005). Tax Evasion and the Proceeds of Crime Act 2002. Legal Studies, 25, 353-337. Andrew, A. (2013). Small Businesses Bear the Brunt of HMRC Crackdown on Tax Evasion as Sum Raked in Jumps 31\%. This Is Money. Available at: http://www.thisismoney.co.uk/money/smallbusiness/article2426603/Small-businesses-bear-brunt-HMRC-crackdown-tax-evasion-sum-recovered-non-compliancejumps-31.html (Accessed 6 March 2019).

Antonopoulos, G. A., \& Hall, A. (2016). The Financial Management of the Illicit Tobacco Trade in the United Kingdom. British Journal of Criminology, 56, 709-728.

Atkinson, C. Mackenzie, S. and Hamilton-Smith, N. (2017). No 9. A Systematic Review of the Effectiveness of Asset-focussed Interventions Against Organised Crime. Available at http://whatworks.college.police. uk/Research/Systematic_Review_Series/Documents/Organised_crime_SR.pdf (Accessed 6 March 2019).

BBC (2017). Magnitsky Bill Turns UK into 'Hostile Environment' for Kleptocrats, Available at: http://www.bbc. co.uk/news/uk-39047321 (Accessed 6 March 2019).

Bonino, S. (2012). Policing Strategies against Islamic Terrorism in the UK after 9/11: The Socio-Political Realities for British Muslims. Journal of Muslim Minority Affairs, 32(1), 5-31.

Box, S. (1983). Power, Crime and Mystification. London and New York: Routledge.

Bristow, K. (2014). Oral evidence taken before the Committee of Public Accounts, on Wednesday 5 January 2014, in House of Commons Committee of Public Accounts, Confiscation Orders, Forty-ninth Report of Session 2013-14. London: HMSO. Available at: http://www.publications.parliament.uk/pa/cm201314 /cmselect/cmpubacc/942/942.pdf (Accessed 6 March 2019).

Burgis, T. (2016). Dark money: London's dirty secret. Financial Times May 11. Available from: https:/urldefense.proofpoint.com/v2/url?u=https-3A www.ft\&d=DwIFg\&c=vh6FgFnduejNhPPD0fl yRaSfZy8CWbWnIf4XJhSqx 8\&r=Ekk4sx4jBO0tUWbfow-G_J1T2AFlHF5QM05H1aBan10\&m=EO $\overline{9}$ sfXH7kNtIWjgpXGiShbD2-_qWyBY1-TrjB741KVo\&s=r3JX3-Y7w67xkTbWpIdv_ayc16wloM62 mpqpSCPPhp0\&e=.com/content/1d805534-1185-11e6-839f-2922947098f0. Accessed 19 Aug 2019.

Bullock, K. (2010). The Confiscation Investigation: Investigating the Financial Benefit Made from Crime. Policing, 4(1), 7-14.

Bullock, K. (2014). Criminal Benefit, the Confiscation Order and the Post-Conviction Confiscation Regime. Crime, Law and Social Change, 62(1), 45-64.

Bullock, K., \& Lister, S. (2014). Confiscation of Criminal Assets in England and Wales: Rhetoric and Reality. In C. King \& C. Walker (Eds.), Dirty Assets: Emerging Issues in the Regulation of Criminal and Terrorist Assets (pp. 47-69). Farnham: Ashgate.

Bullock, K., Mann, D., Street, R. and Coxon, C. (2009). Examining Attrition in Confiscating the Proceeds of Crime. Home Office: Research Report 17. Available at: https://assets.publishing.service.gov. uk/government/uploads/system/uploads/attachment_data/file/116617/horr17-report.pdf. Accessed 19 Aug 2019

CSD. (2015). Financing of Organised Crime. Sofia: $\bar{C}$ enter for the Study of Democracy.

Creedon, M. (2014). Keynote Address: Priorities in a Period of Austerity, in Tackling Missing Trader IntraCommunity Fraud, Disrupting Organised Crime, Developing the Evidence Base to Understand Effective Action. Available at: https://rusi.org/sites/default/files/201411_stfc_disrupting_organised_crime.pdf (Accessed 6 March 2019).

Crown Prosecution Service (2014). CPS Asset Recovery Strategy. https://www.gov. uk/government/uploads/system/uploads/attachment_data/file/248645/Serious_and_Organised_Crime_ Strategy.pdf (Accessed 6 March 2019).

Crown Prosecution Service (2016). Proceeds of Crime Act 2002 - Intellectual Property Crime. London: Crown Prosecution Service. Available at: http://www.cps.gov.uk/legal/h_to_k/intellectual_property_crime/ (Accessed 29 June 2018).

Dorn, N., \& South, N. (1990). Drug Markets and Law Enforcement. British Journal of Criminology, 30(2), 171-188.

European Commission (2009). Assessing the Effectiveness of EU Member States' Practices in the Identification, Tracing, Freezing and Confiscation of Criminal Assets, Final Report, Matrix Insight. Available at http://ec. europa.eu/dgs/home-affairs/what-is-new/news/pdf/final_asset_recovery_report_june_2009_en.pdf (Accessed 6 June 2016).

The European Council (2018) Crime will no longer pay: Council agrees new rules on mutual recognition of freezing and confiscation orders. Press release. Available at: https://www.consilium.europa. eu/en/press/press-releases/2018/06/20/crime-will-no-longer-pay-eu-agree-new-rules-on-mutual-recognitionof-freezing-and-confiscation-orders/ (Accessed 27 June 2019).

FATF (2018). FATF President's Paper: Anti-money laundering and counter terrorist financing for judges and prosecutors. Available at https://www.fatf-gafi.org/media/fatf/documents/reports/AML-CFT-JudgesProsecutors.pdf (Accessed 27 June 2019).

Fleming, M. (2008). Examination of the Means of Establishing the Efficacy of Asset Recovery and Anti-Money Laundering Policies, unpublished PhD thesis. Available at: http://discovery.ucl.ac.uk/1444207/1/U591509. pdf (Accessed 6 March 2019). 
Gallant, M. (2005). Money Laundering and the Proceeds of Crime. Cheltenham: Edward Elgar.

Gallant, M. (2014). Money Laundering Consequences. Journal of Money Laundering Control, 17(3), 296-305.

Goldsmith, A., Gray, D., \& Smith Russel, G. (2014). Criminal Asset Recovery in Australia, in Dirty Assets. Emerging Issues in the Regulation of Criminal and Terrorist Assets (pp. 115-140). Farnham: Ashgate.

GOV.UK (2018). Fraud and error in the benefit system: financial year 2017 to 2018 preliminary estimates. Available at: https:/www.gov.uk/government/statistics/fraud-and-error-in-the-benefit-system-financial-year201718-preliminary-estimates (Accessed 6 March 2019).

Harvey, J., \& Lau, S. F. (2008). Crime Money Records, Recovery and their Meaning. In P. van Duyne, J. Harvey, A. Maljevic, M. Scheinost, \& K. von Lampe (Eds.), European Crime Markets at Cross-Roads (pp. 285307). Tilburg: Wolf Legal.

Harvey, J. (2014). Asset Recovery: Substantive or Symbolic? In C. King \& C. Walker (Eds.), Dirty Assets: Emerging Issues in the Regulation of Criminal and Terrorist Assets (pp. 183-202). Farnham: Ashgate.

Hicks, T. (2015). Model Approach for Investigating the Financing of Organised Crime. Sofia: Center for the Study of Democracy.

HMCTS, (2017). HM Courts \& Tribunals Service 2016-17 Trust Statement, Available at: https://www.gov. uk/government/uploads/system/uploads/attachment_data/file/629879/HMCTS_Trust_Statement 201617 WEB 140717.pdf (Accessed 6 March 2019).

HM Government (2013). Serious and Organised Crime Strategy. London: HMSO. Available at: https:/assets. publishing.service.gov.uk/government/uploads/system/uploads/attachment_data/file/248645/Serious_and Organised Crime Strategy.pdf (Accessed 6 March 2019).

HM Treasury and Home Office (2015). UK National Risk Assessment of Money Laundering and Terrorist Financing. Available at: https://www.gov.uk/government/uploads/system/uploads/attachment data/file/468210/UK_NRA_October_2015_final_web.pdf (Accessed 6 March 2019).

Hobbs, D., \& Antonopoulos, G. (2013). Endemic to the Species: Ordering the 'Other' via Organised Crime. Global Crime, 14(1), 27-51.

Hobbs, D. (2014). Organised Crime as a Community of Practice. In C. Ellis. (Ed.) Disrupting Organised Crime, Developing the Evidence Base to Understand Effective Action, STFC/RUSI Conference series no. 5. Available at: https://rusi.org/sites/default/files/201411 stfc disrupting organised crime.pdf (Accessed 6 March 2019).

House of Commons Home Affairs Committee (2016). Proceeds of crime: Government response to the Committee's Fifth Report of Session 2016-17Contents, Available at: https://publications.parliament. $\mathrm{uk} / \mathrm{pa} / \mathrm{cm} 201617 / \mathrm{cmselect} / \mathrm{cmhaff} / 805 / 80504 . \mathrm{htm}$ (Accessed 6 March 2019).

Home Office (2014). Serious Crime Bill: Proceeds of Crime Act Amendments. Available at: http://www. parliament.uk/documents/impact-assessments/IA14-21C.pdf (Accessed 6 March 2019).

Home Office (2018). Asset Recovery Statistical Bulletin 2012/13-2017/18. Available at: https://assets.publishing. service.gov.uk/government/uploads/system/uploads/attachment_data/file/739567/asset-recovery-financialyears-2013-to-2018-hosb1818.pdf (Accessed 6 March 2019).

Innes, M., \& Sheptycki, J. W. E. (2004). From Detection to Disruption: Intelligence and the Changing Logic of Police Crime Control in the United Kingdom. International Criminal Justice Review, 14, 1-24.

King, C., \& Walker, C. (Eds.). (2014). Dirty Assets. Emerging Issues in the Regulation of Criminal and Terrorist Assets. Farnham: Ashgate.

Kitchener, G. (2017). Paradise Papers: Are We Taming Offshore Finance? BBC. Available at http://www.bbc.co. uk/news/business-41877924 (Accessed 6 March 2019).

Lea, J. (2004). Combatting Organised Crime and Terrorism. John Lea's Website. Available at: http://www. bunker8.pwp.blueyonder.co.uk/orgcrim/3809.htm (Accessed 1 May 2015).

Levi, M. (2016). The Impact of Organised Crime in the EU: Some Preliminary Thoughts on Measurement Difficulties, Contemporary Social Science. Journal of the Academy of Social Sciences, 11(4), 392-402.

Levi, M. (2003). Criminal Asset Stripping. Confiscating the Proceeds of Crime in England and Wales. In A. Edwards \& M. Gill (Eds.), Transnational Organised Crime. London: Routledge.

Levi, M. (1997). Evaluating the 'New Policing': Attacking the Money Trail of Organized Crime. The Australian and New Zealand Journal of Criminology, 30, 1-25.

Levi, M. (2013). Modernising Drug Law Enforcement Report 5, Drug Law Enforcement and Financial Investigation Strategies. International Drug Policy Consortium. Available at: https://orca.cf.ac.uk/88170 /1/MDLE-5-drug-law-enforcement-financial-investigation-strategies.pdf (Accessed 6 March 2019).

Levi, M. (2014). Thinking about Organised Crime. The RUSI Journal, 159(1), 6-14.

Levi, M. (2015). Money for Crime and Money from Crime: Financing Crime and Laundering Crime Proceeds. European Journal on Criminal Policy and Research, 21, 275-297.

Levi, M., \& Maguire, M. (2004). Reducing and Preventing Organised Crime: An Evidence-Based Critique, Crime. Law and Social Change, 41(5), 397-469.

Levi, M., \& Osofsky, L. (1995). Investigating, Seizing and Confiscating the Proceeds of Crime. London: Home Office (Crime Detection and Prevention Series Paper 61). 
Levi, M., \& Reuter, P. (2006). Money Laundering. In M. Tonry (Ed.), Crime and Justice: A Review of Research. Chicago: University of Chicago Press.

Ligeti, K., \& Simonato, M. (2017). Asset Recovery in the EU: Towards a Comprehensive Enforcement Model Beyond Confiscation? An Introduction. In K. Ligeti \& M. Simonato (Eds.), Chasing Criminal Money: Challenges and Perspectives on Asset Recovery in the EU. Oxford: Hart.

Mackenzie, S., \& Hamilton-Smith, N. (2011). Measuring Police Impact on Organised Crime. Performance Management and Crime Reduction. Policing: an International Journal of Police Strategies and Management, 34(1), 7-30.

Magra, I. (2019) 'Britain Is Targeting 'Dirty Money’ With Unexplained Wealth Orders', The New York Times, 30 May. Available at: https:/www.nytimes.com/2019/05/30/world/europe/harrods-unexplained-wealth-order. html (Accessed 30 June 2019).

NAO (2013). Confiscation Orders. London: The Stationery Office. Available at: https://www.nao.org.uk/wpcontent/uploads/2013/12/10318-001-Confiscation-Book.pdf (Accessed 6 March 2019).

NAO (2016). Confiscation Orders. London: The Stationery Office. Available at: https://www.nao.org.uk/wpcontent/uploads/2016/03/Confiscation-orders-progress-review.pdf (Accessed 6 March 2019).

National Crime Agency. (2013). Suspicious Activity Reports (SARs) Annual Report 2013. London: National Crime Agency.

National Crime Agency. (2015). Suspicious Activity Reports (SARs) Annual Report 2015. London: National Crime Agency.

National Crime Agency. (2017). Suspicious Activity Reports (SARs) Annual Report 2017. London: National Crime Agency.

Naylor, T. (1999). Wash-out: A Critique of the Follow-the-Money Methods in Crime Control Policy. Crime, Law and Social Change, 32(1), 1-57.

Naylor, T. (2001). License to Loot? A Critique of Follow-the-Money Methods in Crime Control Policy. Social Justice, 28(3), 121-152.

OECD (2018). Asset Recovery. Available from: https://www.oecd.org/cleangovbiz/toolkit/assetrecovery.htm (Accessed 27 June 2019).

O'Leary, J. (2017). How Much Has the Government Recouped from Tax Evasion and Avoidance?, Full Fact, 2 November. Available from: https://fullfact.org/economy/government-recouped-tax-evasion-avoidance/?utm source $=$ content page \&utm medium=related content (Accessed 6 March 2019).

PIU. (2000). Recovering the Proceeds of Crime (Performance and Innovation Unit). London: Cabinet Office.

Public Accounts Committee (2014). Enforcing Confiscation Orders. Available at: http://www.publications. parliament.uk/pa/cm201314/cmselect/cmpubacc/942/94207.htm (Accessed on 6 March 2019).

Reiman, J. (1979). The rich get richer and the poor get prison: ideology, crime and criminal justice. Boston: Allyn \& Bacon.

Riccardi, M. (2014). When Criminals Invest in Businesses: Are We Looking in the Right Direction? An Exploratory Analysis of Companies Controlled by Mafias. In S. Caneppele \& F. Calderoni (Eds.), Organised Crime, Corruption and Crime Prevention, Essays in Honor of Ernesto U. Savona. Berlin: Springer.

Richards, J. (2016) National Fraud Initiative saves nearly $£ 200 \mathrm{~m}$ in two years. PublicFinance. Available at: https://www.publicfinance.co.uk/news/2016/11/national-fraud-initiative-saves-nearly-ps200m-two-years (Accessed 1 July 2019).

Savona, E.U. and Berlusconi, G. (2015). Organized Crime Infiltration of Legitimate Businesses in Europe: A Pilot Project in Five European Countries. Final Report of EU- co-funded Project ARIEL - Assessing the Risk of the Infiltration of Organized Crime in EU MSs Legitimate Economies: a Pilot Project in 5 EU Countries. Trento: Transcrime - Università degli Studi di Trento.

Savona, E. U., \& Riccardi, M. (Eds.). (2015). From Illegal Markets to Legitimate Businesses: the Portfolio of Organised Crime in Europe, Final Report of EU co-funded Project OCP - Organised Crime Portfolio. Milano: Transcrime - Università Cattolica del Sacro Cuore.

Sedwill, M. (2014). Oral Evidence Taken Before the Committee of Public Accounts, on Wednesday 15 January 2014, in House of Commons Committee of Public Accounts, Confiscation Orders, forty-nine report of session 2013-14. Available at: http://www.publications.parliament.uk/pa/cm 201314 /cmselect/cmpubacc/942/942.pdf (Accessed 6 March 2019).

Serious Crime Act. (2015). Chapter 9. London: The Stationery Office.

Sims, B. (2019). Unexplained Wealth Orders: Not Just for the Super-Rich, available at https://www.risk-uk. com/unexplained-wealth-orders-not-just-for-the-super-rich/ (Accessed 6 March 2019).

Sky (2019) Revealed: What 'McMafia order' wife Zamira Hajiyeva spent £16m on at Harrods, Sky News, 28 May. Available at: https://news.sky.com/story/revealed-what-mcmafia-order-wife-zamira-hajiyeva-spent-16 m-on-at-harrods-11730027 (Accessed 30 June 2019).

Sproat, P. (2009). To What Extent is the UK's Anti-Money Laundering and Asset Recovery Regime Used Against Organised Crime? Journal of Money Laundering Control, 12(2), 134-150. 
Sproat, P. (2012). A Critique of the Official Discourse on Drug and Sex Trafficking by Organised Crime Using Data on Asset Recovery. Journal of Financial Crime, 19(2), 149-162.

Staunton, D. (2018). Oligarchs and 'Unexplained Wealth': London's Rich Russians, The Irish Times, March 24. Available from: https:/www.irishtimes.com/news/world/oligarchs-and-unexplained-wealth-london-s-richrussians-1.3438072 (Accessed 6 March 2019).

Stessen, G. (2000). Money Laundering, a New International Law Enforcement Model. Cambridge: Cambridge University Press.

Stott, C. (2014). Effective and Efficient Disruption: Measuring the Impact of Specific Tactics, in C. Ellis (Ed.) Disrupting Organised Crime, Developing the Evidence Base to Understand Effective Action, STFC/RUSI Conference series no. 5, Available at: https://rusi.org/sites/default/files/201411_stfc_disrupting_organised_ crime.pdf (Accessed 6 March 2019).

Tax Justice Network (2017). Tax Avoidance and Evasion - The Scale of the Problem. Available at: https://www. taxjustice.net/wp-content/uploads/2017/11/Tax-dodging-the-scale-of-the-problem-TJN-Briefing.pdf (Accessed 6 March 2019).

Trainor, S. (2017). What are the Potential Deterrence Effects of Unexplained Wealth Orders? A Criminological Exploration, in Unexplained Wealth Orders: Thoughts on Scope and Effect in the UK, White Collar Crime Centre briefing papers. Available at: https://www.brightlinelaw.co.uk/images/Unexplained_Wealth_Order__Briefing_Papers_Final.pdf (Accessed 6 March 2019).

UK Parliament (2018). Tax Evasion: Prosecutions: Written Question - 126947, UK Parliament Website, 6 February. Available at: https://www.parliament.uk/business/publications/written-questions-answersstatements/written-question/Commons/2018-02-06/126947 (Accessed 6 March 2019).

van Duyne, P. C. (2003). Money Laundering Policy: Fears and Facts. In P. van Duyne, K. von Lampe, \& J. Newell (Eds.), Criminal Finance and Organizing Crime in Europe. Tilburg: Wolf Legal.

Vitou, B. and Ottaway, A-M. (2019). Failure to Prevent Tax Evasion: Forgotten, but Not Gone, Greenberg Traurig Blog, 2 January. Available at: https://www.gtlaw.com/en/insights/2019/1/failure-to-prevent-taxevasion-forgotten-but-not-gone (Accessed 30 June 2019).

Wall, D. and Chistyakova, Y. (2015). Organised Crime in the United Kingdom. In E.U. Savona and M. Riccardi (Eds.), From Illegal Markets to Legitimate Businesses: The Portfolio of Organised Crime in Europe, Final Report of EU co-funded Project Organised Crime Portfolio (Chapters 5.7, 8.7, 10.9 and 12.8). Milano: Università Cattolica del Sacro Cuore.

Wall, D.S. and Bonino, S. (2015). Organised Crime Infiltration of Legitimate Economies in the UK. In E.U. Savona and G. Berlusconi (Eds.) Organized Crime Infiltration of Legitimate Businesses in Europe: A Pilot Project in Five European Countries. Final Report of EU-co-funded Project ARIEL - Assessing the Risk of the Infiltration of Organized Crime in EUMSs Legitimate Economies: a Pilot Project in 5 EU Countries (pp. 67-74). Trento: Transcrime - Università degli Studi di Trento.

Wall, D., Chistyakova, Y., \& Bonino, S. (2016). Organised Crime Infiltration in the UK: Crash-for-cash and VAT Carousel Fraud. In E. U. Savona, M. Riccardi, \& G. Berlusconi (Eds.), Organised Crime in European Businesses (Chapter 7). London: Routledge.

Webb, O. (2018). Revealed: not a single person has been prosecuted under the Tories' offshore tax evasion laws, Left Foot Forward, 12 March. Available at: https://leftfootforward.org/2018/03/not-a-single-person-hasbeen-prosecuted-under-the-tories-offshore-tax-evasion-laws/ (Accessed 10 September 2018).

Whyte, D., \& Wiegratz, J. (2016). The Moral Economy of Neoliberal Fraud. In D. Whyte \& J. Wiegratz (Eds.), Neoliberalism and the Moral Economy of Fraud. New York: Routledge.

Wood, H. (2016a). Enforcing Criminal Confiscation Orders, from Policy to Practice, RUSI Occasional paper. Available at: https://rusi.org/sites/default/files/201602_op_enforcing_criminal_confiscation_orders.pdf (Accessed 23 June 2016).

Wood, H. (2016b). The Big Payback, Examining Changes in the Criminal Confiscation Orders Enforcement Landscape, RUSI Occasional paper. Available at: https://rusi.org/sites/default/files/201602_op_the_big_ payback.pdf (Accessed 24 June 2016).

Woodiwiss, M. (2003). Transnational Organised Crime: The Global Reach of an American Concept. In A. Edwards \& M. Gill (Eds.), Transnational Organised Crime. London: Routledge.

Zucman, G. (2017). The desperate inequality behind global tax dodging. The Guardian. Available at: https://www.theguardian.com/commentisfree/2017/nov/08/tax-havens-dodging-theft-multinationalsavoiding-tax (Accessed 28 June 2018).

Publisher's Note Springer Nature remains neutral with regard to jurisdictional claims in published maps and institutional affiliations. 